\title{
Effect of Using Different Types of Silages Mixtures in Dairy Goat Diets on Milk Production, Feed Conversion, Rumen Fermentation, Nutritional Value and Blood Components.

\author{
Animal Production Research Institute, Agricultural Research Center, Dokki, Giza, Egypt.
} \\ El-Kholany, M. E.; G. A. Maged; W. M. A. Sadik and A. A. Mehany
}

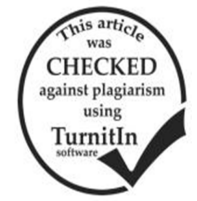

\section{ABSTRACT}

This work was carried out on lactating goats to investigate the effect of partial replacing concentrate feed mixture (CFM) proteins by some types of silages on milk production, feed conversion and some metabolic parameters as well as economic efficiency. Eighteen dairy Zaraibi goats with average body weight $40.00 \mathrm{~kg}$ were divided into 3 groups (6 each). All animals were fed concentrate feed mixture (CFM) to cover 50\% of their requirements recommended by NRC (1981). Treatments experimented were $50 \% \mathrm{CFM}+50 \%$ berseem silage as control rations $(\mathrm{G} 1), 50 \% \mathrm{CFM}+50 \%$ mixture silage $(50 \%$ berseem + $50 \%$ fodder beet) (G2), $50 \%$ CFM $+50 \%$ mixture silage ( $50 \%$ Ses bania $+50 \%$ fodder beet) (G3) as tested rations. In addition, nine adult Zaraibi males ( 3 males per each group) were used with three digestion trails to evaluate the feeding values of the experimental. Results indicated that daily total DM intake per head and as $\mathrm{g} / \mathrm{kg} 0.75$ tended to silage by decrease with tested rations (G2 and G3) compared with G1, being 1132 and 1102 vs. $1152 \mathrm{~g} / \mathrm{h}$ and 70.93 and $69.64 \mathrm{vs.} 72.68 \mathrm{~g} / \mathrm{kg} 0.75$ respectively. Ruminal $\mathrm{pH}$ values were not significantly affected by treatments. While, ammonia-N concentrations tended to be significant lower with G2 and insignificant lower with G3 compared with control (G1). The opposite trend was occurred with microbial protein concentrations among treatments. Also, ruminal TVF,s concentrations were significantly increased by tested rations (G2, G3) compared with that of control one (G1) especially over 3 an 6 sampling fame . Comparison of hematological parameters revealed small fluctuations among groups fed the experimental rations in concentrations of Hb, RBC,s, Hct, MCHC, platelet and albumin. On the other hand, both total protein and globulin were also higher $(7.21$ and $4.36 \mathrm{~g} / \mathrm{dl})$ with G2 than those of the other group but without significance differences among them. Both AST and Alt concentrations were higher with G1 ( 17.68 and 155.00, respectively) than other groups and the differences were significant in AST activity only and just between G1 and G2. Concerning $\mathrm{Ca}$ and ph contents in blood, Scanty differences among the dietary treatments, however it could be observed some significant differences among treatments. Digestion coefficients of most nutrients and feeding values did not affected by the experimental treatments, otherwise CP digestibility and DCP values were significant improved by Sesbania- fodder beet silage rations (G3) than the control (G1) and the other tested rations (G2) milk yield was the highest with G3 followed by (G2), while the lowest yield with G1 and the differences were significant only between G3 and G1. Milk composition as fat, protein, lactose, total solids, solid non fat and ash was unaffected significantly by the tested rations. Accordingly, the feed conversion efficiency was better with G3 (0.82 and 0.123 , respectively) and G2 ( 0.869 and 0.118 , respectively) compared with berseem silage alone, G1 (0.93 and 0.134, respectively). Similarly, the economic efficiency was better with G3 compared with the other groups.

Keywords: Lactating goats- mixture silage- Sesbania sesban - fodder beet- berseem - rumen parameters- productive performance.

\section{INTRODUCTION}

Nutrition is a major factor affecting the physiological and metabolic status consequently the productive performance of farm animals. In Egypt, there is wide gap between the available feedstuffs and the nutritional requirements of animals population. During summer season, green forage with reasonable protein contents are not adequately available.

According to national policy. The cultivated area with clover would-be tending to decrease for increase lthe cultivated larea with wheat to satisfy human demands. Several studies (Tag El-Din, 1991, Shehata et al, 2001 Maged et al,2014) indicated that wild plants as Sesbania sesban could be used as a good quality forage for ruminants because of its high content of crude protein and feeding values especially when harvested during earlier growth stage. Moreover, Soliman et al. (1997) and El-Kholany (2004) stated that the value of CP digestibility and DCP were higher with Sesbania (forage or silage) rations compared with teosinte or whole corn plants. Recent studies indicated that Sesbania sesban in different forms (forage, silage or seeds) had positive effects on farm animals performance as reported by Ahmed et al. (2009), Ibrahim et al.(2012) and El-Kholany et al(2016).Among important forage croups in Egypt, fodder beet could be recommended as one of the highest producing in loamy soils and reclamation areas and it was found to be a good source of energy for animal feeding (Rammah et al 1984). Fodder beet could play an important role for feeding livestock in summer in Egypt, using either in fresh or after in ensilage states for cows (Gabra et al, 1992). Therefore, the main objective of this study was to recognized the effect of restriction of concentrate feed mixture (CFM) with some types of silage mixtures berseem with (Sesbania / or fodder beet) given at adlibitum level on milk and its composition, feeding values, feed conversion and economic efficiency of Zaraibi goats. Also, some rumen parameters and blood profile were investigated.

\section{MATERIALS AND METHODS}

This study was conducted in El-Serw Experimental Research Station, Animal Production Research Institute, Agricultural Research Center, Ministry Of Agriculture, Egypt. Eighteen lactating Zaraibi does, chosen from El-Serw Station Herd, with an range age of 3-6 years and 40.19 \pm 0.33 $\mathrm{kgl}$ live body weight were randomly divided into 3 similar groups (6 of each) for feeding trials using randomized complete block design. Animals were weighed at the beginning then biweekly along experimental period that lasted 14 weeks. Zaraibi goats in all groups were fed restricted amount of concentrate feed mixture (CFM) to cover $50 \%$ of total protein requirements which recommended by NRC (19981) for lactating goats in addition a combination of different silages was fed adlib. as follows:

Control ration (G1): $\mathrm{CFM}+$ berseem (trifolium alexandarinum) (2nd cut) silage (G1) ad lib.

Tested ration G(2): CFM+ $(50 \%$ berseem $+50 \%$ fodder beet) silage ad lib.

Tested ration (G3) : $\mathrm{CFM}+(50 \%$ Sesbania sesban + $50 \%$ fodder beet )silage ad lib.

Animals were fed by groups feeding system in a suitable partition pens. The berseem and fodder beet were cultivated in El-Serw experimental station, while 
Sesbania sesban were collected from ridge and canals near the same farm.

Berseem silage was prepared by adding $3 \%$ molasses, on fresh basis, while mixture silages prepared without any additives according to Ahmed et al (2001 and 2003).

The CFM was consisted of $25 \%$ undecortecated cotton meal, $43 \%$ yellow corn, $25 \%$ wheat bran, $3.5 \%$ molasses, $2 \%$ limestone, $1 \%$ common salt and $0.5 \%$ minerals mixtures concentrate feed mixture (CFM) consists of $43 \%$ yellow corn, $25 \%$ undecortecated cotton meal, $25 \%$ wheat bran, 3.5 molasses, $2 \%$ limestone, $1 \%$ commonlsalt. Rations were offered twice daily at 8.0 am and at 3.0 p.m while water was available at all times. The chemical analysis of CFM and different types of silages are presented in Table (1). Samples of feed and feces were analyzed according to the procedures of A.O.A.C (1995). Fiber fractions (NDF, $\mathrm{ADF}$ and $\mathrm{ADL}$ ) of ration ingredients as well as silages were determined according (Robertson and Vanlsoset, 1981).

Cellulose (ADF\% - ADL\%), and hemicelluloses $(\mathrm{NDF} \%$ - $\mathrm{ADF} \%)$ contents were calculated by the difference. Blood samples were collected from the jugularlvein once before feeding ( 3 animals from each treatment) at the lend of experimental period. Blood samples were centrifuged at $4000 \mathrm{rpm}$ for 20 minutes. Part of the separated serum was directed to enzymes activity determination, while the other part was stored at-20 Co till the biochemical analysis time.

Commercial kits were used for colorimetric biochemical determinations. Different items of the blood picture tested in this experimental were carried out according to the corresponding references illustrated in the following table :

\begin{tabular}{ll}
\hline Criteria & \multicolumn{1}{c}{ References } \\
\hline Hemoglobin (HG) & Linne and Ringsrud (1992) \\
Red blood cell (RBC's) & Miller and Weller (1971) \\
GOT and GPT & Retiman and Frankel (1957) \\
Total protein & Doumas et al. (1981) \\
Albumin & Hill and Wells (1983) \\
\hline
\end{tabular}

The daily milk yield was recorded for each doe and representative milk samples (about $0.5 \%$ of total milk produced) were taken once biweekly from each goat from the morning and evening milking of the same day. Then the samples were compared and analyzed for total solids (T.S), fat, protein, solid non fat (SNF) and ash according to Ling procedures (1963), while milk lactose was calculated by differences.

Rumen fluid samples were taken from 3 animals of experimental group using stomach tube before feeding $(0$ time) and at 2,4,6 and $8 \mathrm{hrs}$ post-feeding. The samples were filtered through 3 layers of gauze and immediately subjected to the determination of $\mathrm{pH}$ value by $\mathrm{pH}$ meter, ammonia nitrogen $(\mathrm{NH} 3-\mathrm{N})$ concentration was measured according to method Conway (1957), total volatile fatty acids (TVF,s) was determined according to the technique described by Warner (1964), whereas microbial protein was determined according to Schultz and Schultz (1970). The economic efficiency was calculated as ratio between output (price of milk yield) and cost of feed consumed according to the local price during the study .

In addition, 3 digestibility trails were conducted using 9 adult Zaraibi bucks to evaluate the digestibility and feeding values of the tested diets. Data were statistically analyzed using SAS (2003) and the significant differences among means were assigned using Duncan multiple rang test methods (Duncan, 1955).

\section{RESULTS AND DISCUSSION}

\section{Chemical composition of the experimental diets:}

The chemical composition of the CFM and the tested silages are presented in Table (1). It could be observed that most of nutrients of DM and CF-fractions were slightly higher with Sesbania / fodder beet silage mixture (G3) compared with those of the other silage types while the contents NFE seemed to be in an inverse trend among the silage types. Mostly the lowest values were occurred with berseem silage (G1). However, considerably the contents of $\mathrm{CP}$ and $\mathrm{CF}$ (the two key elements of feeding rumenants) of all silage typs are significantly favorable for farm animals (sheep, goats and cattle). Usually the addition of starchy crop like fodder beet intolhiguminous crop like berseem atlsilage making could be mesulting a very good balbncel of nutrents especially $\mathrm{CP}$ and $\mathrm{CF}$ contents of the produced silage.

Similar results on the some types of tested silages were reported by Maged et al. (2014). In this respect, Ahmed et al. (2013) found that berseem silage contained $29.5 \%$ DM, 87.95 OM, 29.67\% CF, $14.15 \%$ $\mathrm{CP}, 2.03 \% \mathrm{EE}, 42.10 \% \mathrm{NFE}$ and $12.05 \%$ Ash.

Table 1. Chemical composition of feed ingredients (\%) on DM basis

\begin{tabular}{|c|c|c|c|c|}
\hline \multirow[b]{2}{*}{ Items } & \multicolumn{4}{|c|}{ Silages } \\
\hline & $100 \%$ Berseem & $\begin{array}{c}50 \% \text { Berseem }+50 \% \\
\text { Fodder beet }\end{array}$ & $\begin{array}{c}50 \% \text { Sesbania sesban }+ \\
50 \% \text { Fodder beet }\end{array}$ & CFM \\
\hline$\overline{\mathrm{DM}}$ & 29.32 & 27.30 & 30.75 & 91.00 \\
\hline $\mathrm{OM}$ & 88.00 & 89.50 & 88.84 & 93.90 \\
\hline $\mathrm{CF}$ & 28.85 & 22.15 & 29.11 & 15.70 \\
\hline $\mathrm{CP}$ & 14.30 & 12.75 & 15.65 & 14.5 \\
\hline $\mathrm{EE}$ & 2.19 & 2.35 & 2.78 & 3.15 \\
\hline NFE & 44.35 & 52.25 & 42.33 & 60.55 \\
\hline Ash & 12.00 & 10.50 & 10.16 & 6.10 \\
\hline NDF & 56.20 & 58.40 & 61.50 & 43.50 \\
\hline ADF & 38.30 & 39.20 & 40.60 & 19.30 \\
\hline ADL & 7.0 & 6.50 & 7.40 & 4.70 \\
\hline Hemicelluloses & 17.90 & 19.20 & 20.90 & 24.20 \\
\hline Cellulose & 31.30 & 32.70 & 33.20 & 14.60 \\
\hline
\end{tabular}

Silagelquality:

The different silages had a good physical characteristics expressed as natural color and pleasant aroma as well as a good fermentative quality (Table, 2) that expressed as very suitable range of $\mathrm{PH}(3.95$ to
$4.33 \%)$, and lactic acid (5.80 to 6.5\%) and least contents of butyric acid and ammonia-N.

Definitely $\mathrm{Ph}$ concentration were in normal range of good silage quality, being $3.95,4.20$ and $4.35 \%$ for berseem, berseem plus fodder beet and Sesbania plus fodder silages, respectively. The same trend was 
observed with acetic concentration, where Sesbania plus fodder beet silage had the lowest concentrationlof acetic acid $(2.20 \%)$ followed bylberseem plus fodderlbeet $(2.30 \%)$ andlberseem silage $(2.42 \%)$. In thislrespect, butyriclacid concentrationlrecorded $0.23,0.32$ and $0.36 \%$ forlberseem, berseem plus fodderlbeet and Sesbania pluslfodder beetlsilages, respectively, being theselvalues are considere as one of good indicatorslfor good quality silagelproduced. Ammonia-N concentrationltook the same trend oflbutyric acid concentration. Theselresults are in linelwith the finding oflShehata et al (2001) with Kochialsilage and/or teosinte silage, Maged et al. (2014) and El-Sayed, F.A. et al(2015) withldifferent forages silages.

The daily waterlconsumption with Sesbaniafodder beet silage was markedly higher than with thelothers (G1 and G2) which is mostly due tolthe halophytic effect of Sesbania sesban as reported by Ahmed et al. (2001) and Shehata et al. (2001) who using Kochia silage in goats rations.

Table 2. Some fermentative quality criteria of different silages tested.

\begin{tabular}{lccc}
\hline \multirow{2}{*}{ Items } & \multicolumn{3}{c}{ Groups } \\
\cline { 2 - 4 } & $\mathbf{G}_{\mathbf{1}}$ & $\mathbf{G}_{\mathbf{2}}$ & $\mathbf{G}_{\mathbf{3}}$ \\
\hline Ph value & 3.95 & 4.20 & 4.35 \\
Lactic acid,\% DM & 6.50 & 6.25 & 5.80 \\
Acetic acid, \% DM & 2.42 & 2.30 & 2.20 \\
Butyric acid, \% DM & 0.23 & 0.32 & 0.36 \\
Ammonia-N, \% DM & 0.16 & 0.20 & 0.23 \\
\hline
\end{tabular}

Table 3. Feed intake and water consumption by lactating Zaraibi goats fed the experimental rations.

\begin{tabular}{lccc}
\hline \multirow{2}{*}{ Items } & \multicolumn{3}{c}{ Groups } \\
\cline { 2 - 4 } & $\mathbf{G}_{\mathbf{1}}$ & $\mathbf{G}_{\mathbf{2}}$ & $\mathbf{G}_{\mathbf{3}}$ \\
\hline Average BW, kg & 39.80 & 40.20 & 40.0 \\
Metabolic body size, w ${ }^{0.75}$ & 15.85 & 15.96 & 15.91 \\
CFM & 532 & 522 & 518 \\
Silage & 620 & 610 & 590 \\
Total DM intake & 1152 & 1132 & 1108 \\
DM intake, g/kg w 075 & 72.68 & 70.93 & 69.64 \\
Roughage : Concentrate ratio & $54: 46$ & $54: 46$ & $53: 47$ \\
\hline Daily water consumption & & & \\
L/ h / d & 3.93 & 3.95 & 4.10 \\
Ml / kg BW & 99 & 98 & 102 \\
Ml /kg w 0.75 & 248 & 247 & 257 \\
Ml /g DM intake & 3.41 & 3.49 & 3.70 \\
\hline
\end{tabular}

- Group feeding

Ruminal fermentation parameters:-

Data of some ruminal liquor parameters of Zaraibi goats fed the experimental rations are presented in (Table,4). The maximum $\mathrm{pH}$ values were recorded at 0 time sampling with all groups without significant differences among treatments and then decreased to the minimum values at 3 hrs post-feeding and tended to increaselagain at $6 \mathrm{hrs}$ postfeeding with all groups and also the differences among the dietary treatments did not significant over the two sampling times. Similar trends were observed by Zaid et al (2009) and Ibrahim et al, (2012) with Zaraibi kids and Rahmani lambs, respectively. otherwise, ruminal ammonia-N concentration was greatly increased post-feeding where. The maximum values of ruminallNH3were observed at $3 \mathrm{hrs}$ post-feeding samples then decreased at $6 \mathrm{hrs}$ post-feeding with all dietary treatments.

Differences among treatments respecting ammonia-N concentration was not significant at zero sampling time, while at $3 \mathrm{hrs}$ post-feeding sampling time, ammonia-N concentration of G2 was lower significantly $(\mathrm{P}<0.05)$ than $\mathrm{G} 1$ and in significant than
G3. Similar trend was observed in case ofl6 hrs postfeeding sample. The marked variation regarding ammonia-N concentrations among treatments are in concordant with the variation of $\mathrm{CP}$ content in the different types of silage and the whole rations as well. Also, it could be observed on opposite relationship between ammonia- $\mathrm{N}$ concentration values and the microbial protein content values especially over 3, $6 \mathrm{hrs}$ sampling time, over all dietary treatments. Concentration of TVF's at zero sampling time did not significant affected by treatments. While concentrations of TVF's post feeding (3 and 6hrs) were significant higher with the two tested rations (G2 and G3) than that of control one (G1). Similar results were observed by Zaid et al (2009) and El-Kholany et al, (2013).

Similar findings were found by Haggag et al (2002), El-Kholany (2004) who using mixture forageland silagelin Rahmani sheep and Zaraibi goats. El-Emam et al (2014) found that ruminal total VFA's concentrationslover 3 and 6 hrs post-feeding significantly lower with berseem silage group thanlthose of triticale silage or berseem/triticale silage.

Ruminal microbial protein was not significantly different among three treatments at zero time and was significantly $(\mathrm{P}<0.05)$ higher with $\mathrm{G} 2$ and G3 than that of berseem silage (G1) over sampling at 3 and $6 \mathrm{hrs}$ postfeeding. This positive effect of mixture silage onlrumina microbial protein was observed also by Shehata et al (2001), Ibrahim et al (2012) and Ahmed et al (2013) in the rumen of bucks, lambs and lactating does, respectively. In perspective, protein is the most important factor in maintaining the rumen ecosystem, stimulating dry matter intake as well as digestibility and leading to high animal performance. So under the malnutrition conditions in developing sub/tropical counters, fodder trees and shrub legumes such as Lucerne (Nguyen et al (2017) and like wild Sesbania sesban that used in the present study, were beneficially used as a valuable source of $\mathrm{CP}$ under these harsh conditions for monitoring the rumen function.

Table 4. Effect of the experimental rations on some ruminal fermentative parameters of dairy goats.

\begin{tabular}{lcccc}
\hline \multirow{2}{*}{ Items } & \multirow{2}{*}{ Hours } & \multicolumn{4}{c}{ Groups } \\
\cline { 3 - 5 } & & $\mathbf{G}_{\mathbf{1}}$ & $\mathbf{G}_{\mathbf{2}}$ & $\mathbf{G}_{\mathbf{3}}$ \\
\hline $\mathrm{pH}$ & 0 & $7.03 \pm 0.06$ & $7.05 \pm 0.09$ & $6.98 \pm 0.03$ \\
& 3 & $6.45 \pm 0.04$ & $6.49 \pm 0.04$ & $6.53 \pm 0.06$ \\
Ammonia-N & 6 & $6.75 \pm 0.04$ & $6.73 \pm 0.06$ & $6.70 \pm 0.04$ \\
$(\mathrm{mg} / 100 \mathrm{ml})$ & 0 & $16.90 \pm 0.40$ & $17.00 \pm 0.30$ & $17.08 \pm 0.20$ \\
& 3 & $23.10 \pm 0.35^{\mathrm{a}}$ & $21.90 \pm 0.11^{\mathrm{b}}$ & $22.11 \pm 0.28^{\mathrm{ab}}$ \\
Total VFA's & 6 & $21.50 \pm 0.40^{\mathrm{a}}$ & $20.03 \pm 0.21^{\mathrm{b}}$ & $20.70 \pm 0.30^{\mathrm{ab}}$ \\
(mEq / 100ml) & 0 & $8.85 \pm 0.19$ & $9.05 \pm 0.08$ & $9.00 \pm 0.19$ \\
& 3 & $11.71 \pm 0.13^{\mathrm{b}}$ & $12.92 \pm 0.36^{\mathrm{a}}$ & $12.69 \pm 0.18^{\mathrm{a}}$ \\
Microbial protein & 6 & $11.03 \pm 0.12^{\mathrm{b}}$ & $12.05 \pm 0.25^{\mathrm{a}}$ & $11.90 \pm 0.17^{\mathrm{a}}$ \\
(g/ 100m) & 3 & $0.355 \pm 0.02$ & $0.349 \pm 0.01$ & $0.341 \pm 0.02$ \\
& 6 & $0.463 \pm 0.017^{\mathrm{b}}$ & $0.595 \pm 0.01^{\mathrm{a}}$ & $0.585 \pm 0.01^{\mathrm{a}}$ \\
& & $0.017^{\mathrm{b}}$ & $0.500 \pm 0.01^{\mathrm{a}}$ & $0.483 \pm 0.01^{\mathrm{a}}$ \\
\hline
\end{tabular}

a-b Means in the same row with different superscripts differ significantly at $\mathbf{P}<0.05$.

Blood parameters :-

Data of hemato-biochemical parameters are presented in Table (5). Results indicated that most tested blood parameters did not significantly affected by the tested rations. It could be observed that almostly all values of hematological parameters (red blood cells, hemoglobin, $\mathrm{Hct}, \mathrm{MCV}, \mathrm{MCH}$ and $\mathrm{MCHC}$ ) were slightly higher with tested rations(G2 and G3) than those of control one (G1).

Also, slightly differences among experimental rations respecting the total leukocytes count and its 
differential cells(Neutrophils, lymphocytes, Monocytes, Eosinophils and platelet count), were observed. Similarly, minor differences among treatments were observed in respect of total protein, albumin and globulin concentrations. Beneficially, the hematological data was used as an indication of the health status of the goats. Fed the experimental diets. The similarly of blood total protein, albumin and globulin concentrations among treatments might be greatly due to the similarity of $\mathrm{CP}$ contents and its intake such treatments (Table1). Inconsistent, Figueiras et al.(2016) revealed that the excess of protein in diets of cattle led to increased the elimination of nitrogenous compounds via urine. Regarding creatinine concentration, no significant difference among treatments were observed. Creatinine levels were within the normal range and they were comparable with the finding of Elitok (2012). Both AST and ALT concentration were higher with G1 (17.68 and 155, respectively) than other groups and the differences were significant in AST concentration only. Higher liver enzymes were associated with lower nutrient intake Oni et al., 2006) which indicated that goats fed the experimental diets had adequate amounts of nutrients to sustain their maintenance and milk production. Concerning $\mathrm{Ca}$ and ph contents in blood, despite diminishing differences among treatments, $\mathrm{Ca}$ content with $\mathrm{G} 3$ rations was lesser significantly than that of G2 and insignificantly than that of G1 ration. While ph content was higher significantly with both tested rations than that of control one.

Generally, the obtained values are within the normal physiological ranges reported by Jain (1986) and Keneko (1989) for healthy goats and in the line with findings of Gabrlet al (1999), El-Kholany (2004) and Ibrahim et al. (2008 and 2012) who used mixture of silage (or forage) in small ruminant rations.

Table 5. Effect of experimental treatments on some hematological and serum biochemical parameters of lactating goats.

\begin{tabular}{|c|c|c|c|}
\hline \multirow{2}{*}{ Items } & \multicolumn{3}{|c|}{ Groups } \\
\hline & $\mathbf{G}_{1}$ & $\mathbf{G}_{2}$ & $\mathbf{G}_{3}$ \\
\hline \multicolumn{4}{|l|}{ Hematological parameters:- } \\
\hline $\mathrm{RBC}^{\prime} \mathrm{s} \times 10^{6} / \mathrm{ml}$ & $13.45 \pm 0.54$ & $13.63 \pm 0.96$ & $14.02 \pm 1.15$ \\
\hline Hemoglobin, g/dl & $10.36 \pm 0.65$ & $10.81 \pm 0.11$ & $11.42 \pm 0.77$ \\
\hline Hct $\%$ & $29.50 \pm 0.93$ & $30.26 \pm 0.33$ & $31.33 \pm 1.45$ \\
\hline $\mathrm{MCV}, \mathrm{fl}$ & $21.13 \pm 1.40$ & $21.55 \pm 1.43$ & $21.88 \pm 1.57$ \\
\hline $\mathrm{MCH}, \mathrm{pg}$ & $7.66 \pm 0.39$ & $7.97 \pm 0.54$ & $8.39 \pm 1.28$ \\
\hline $\mathrm{MCHC}, \mathrm{g} / \mathrm{dl}$ & $36.60 \pm 2.46$ & $36.87 \pm 0.36$ & $37.81 \pm 3.47$ \\
\hline Total leukocyte count, $\mathrm{x} 10^{3} / \mathrm{ml}$ & $10.51 \pm 3.10$ & $12.35 \pm 1.00$ & $13.30 \pm 2.02$ \\
\hline Neutrophils, \% & $42.00 \pm 1.15$ & $42.69 \pm 0.90$ & $42.35 \pm 0.34$ \\
\hline Lymphocytes, \% & $54.36 \pm 0.87$ & $53.34 \pm 1.51$ & $54.69 \pm 0.88$ \\
\hline Monocytes, $\%$ & $2.01 \pm 0.57$ & $2.70 \pm .35$ & $1.67 \pm 0.67$ \\
\hline Eosinophils, \% & $1.56 \pm 0.33$ & $1.36 \pm 0.33$ & $1.36 \pm 0.33$ \\
\hline Platelet count, $\mathrm{x} 103 / \mathrm{ml}$ & $360 \pm 11.70$ & $383 \pm 8.85$ & $395 \pm 18.11$ \\
\hline \multicolumn{4}{|l|}{ Serum biochemical :- } \\
\hline Total protein, $\mathrm{g} / \mathrm{dl}$ & $7.01 \pm 0.13$ & $7.21 \pm 0.15$ & $7.09 \pm 0.19$ \\
\hline Albumin, g/dl & $2.75 \pm 0.30$ & $2.85 \pm 0.13$ & $2.98 \pm 0.12$ \\
\hline Globulin, g/dl & $4.26 \pm 0.34$ & $4.36 \pm 0.27$ & $4.11 \pm 020$ \\
\hline Creatinine, $\mathrm{mg} / \mathrm{dl}$ & $0.95 \pm 0.06$ & $0.84 \pm 0.06$ & $1.04 \pm 0.09$ \\
\hline $\mathrm{AST}, \mathrm{m} / \mathrm{l}$ & $17.68 \pm 0.68^{\mathrm{a}}$ & $14.75 \pm 0.87^{\mathrm{b}}$ & $15.70 \pm 0.32^{\mathrm{ab}}$ \\
\hline $\mathrm{ALT}, \mathrm{m} / 1$ & $155 \pm 10.33$ & $147 \pm 18.78$ & $149 \pm 4.95$ \\
\hline Calcium, mg/ dl & $10.55 \pm 0.13^{\mathrm{ab}}$ & $10.63 \pm 0.08^{\mathrm{a}}$ & $10.30 \pm 0.06^{\mathrm{b}}$ \\
\hline Phosphorus (inorganic), $\mathrm{mg} / \mathrm{dl}$ & $8.10 \pm 0.03^{\mathrm{b}}$ & $8.31 \pm 0.03^{\mathrm{a}}$ & $8.25 \pm 0.03^{\mathrm{a}}$ \\
\hline
\end{tabular}

a-b Means in the same row with different superscripts differ significantly at $\mathbf{P}<0.05$.

Digestion coefficients and feeding value:-

The effects of tested rations on digestion coefficients of most nutrients were not significant when compared with control one as shown in (Table 6). Only CP digestibility was higher in G3 (72.24\%) then that oflG2 ( $70.75 \%)$ and G1 (71.05\%). This result was related to the crude protein content as reported earlier in (Table 1). Otherwise, very slightly differences among treatments in respect of TDN value were observed. Similar results were observed by Shehata et al.(2001) with substitution Teosinte forage by Kochialin silage form and offered with concentrate mixture to Zaraibilbucks. The highest values of DCP were observed with G3 (10.57\%) then followed by G2 $(9.60 \%)$ and the lowest value was associated with control one (G1) as $(9.45 \%)$. Similar results were observed by Shehata et al (2001) and Ibrahim et al (2012) with goats and sheep fed rations containing Kochia and Sesbania silages, respectively. El-Kholany (2004) found that digestion coefficients (DM, OM, CF, $\mathrm{CP}$ and EE) and feeding value (TDN and DCP) of maize- Sesbania mixture was higher than both of maize and Sesbania silages when singly tested. The adequacy of CP content of all experimental rations in the present experimental could be concederable led to an achievement for optimum microbial digestion of feed consumed and hence the digestibility of most nutrients seemed to be fully satisfied as shown in Table 6 .

Milk yield and its composition:-

Data presented in Table (7) showed the effect of tested rations on average milk yield and its composition. The obtained results indicated that daily milk yield of 
Zaraibi goats was significantly higher with G3 Than that of G1 while milk yield of berseem-fodder beet silagelration (G2) was insignificant higher than that of berseem silage ration (G1), being 1.230, 1.315 and $1.355 \mathrm{~kg}$ for $\mathrm{G} 1, \mathrm{G} 2$ and $\mathrm{G} 3$, respectively.

Table 6. Digestion coefficients and feeding value of experimental rations fed to Zaraibi bucks.

\begin{tabular}{|c|c|c|c|}
\hline \multirow{2}{*}{ Items } & \multicolumn{3}{|c|}{ Groups } \\
\hline & $\mathbf{G}_{1}$ & $\mathbf{G}_{2}$ & $\mathbf{G}_{3}$ \\
\hline \multicolumn{4}{|c|}{ Digestibility, (\%) } \\
\hline DM & $67.05 \pm 0.69$ & $66.80 \pm 0.59$ & $67.92 \pm 0.73$ \\
\hline $\mathrm{OM}$ & $70.61 \pm 0.46$ & $69.83 \pm 1.06$ & $68.55 \pm 0.43$ \\
\hline $\mathrm{CF}$ & $63.20 \pm 0.49$ & $62.65 \pm 0.56$ & $63.08 \pm 0.24$ \\
\hline $\mathrm{CP}$ & $71.05 \pm 0.55^{\mathrm{b}}$ & $70.75 \pm 0.33^{b}$ & $72.24 \pm 0.48^{\mathrm{a}}$ \\
\hline $\mathrm{EE}$ & $81.00 \pm 0.66$ & $79.83 \pm 0.42$ & $80.20 \pm 0.58$ \\
\hline NFE & $70.85 \pm 0.75$ & $69.20 \pm 0.70$ & $68.85 \pm 0.61$ \\
\hline \multicolumn{4}{|c|}{ Feeding values, (\%) } \\
\hline TDn & $66.10 \pm 0.34$ & $65.85 \pm 0.50$ & $65.50 \pm 0.44$ \\
\hline $\mathrm{DCP}$ & $9.45 \pm 0.05^{\mathrm{b}}$ & $9.60 \pm 0.07^{b}$ & $10.57 \pm 0.06^{\mathrm{a}}$ \\
\hline
\end{tabular}

Table 7. Effect of feeding experimental rations on milk production, its composition and yield of fat and protein of Zaraibi goats.

\begin{tabular}{lccc}
\hline \multirow{2}{*}{ Items } & \multicolumn{3}{c}{ Groups } \\
\cline { 2 - 4 } & $\mathbf{G}_{\mathbf{1}}$ & $\mathbf{G}_{\mathbf{2}}$ & $\mathbf{G}_{\mathbf{3}}$ \\
\hline Daily milk yield, kg/h/d & $1.230 \pm 0.07^{\mathrm{b}}$ & $1.315 \pm 0.05^{\mathrm{ab}}$ & $1.355 \pm 0.02^{\mathrm{a}}$ \\
\hline Milk composition, \% & & \\
Fat, \% & $4.0 \pm 0.06$ & $4.03 \pm 0.05$ & $4.05 \pm 0.07$ \\
Protein, \% & $3.02 \pm 0.04$ & $3.03 \pm 0.05$ & $3.07 \pm 0.03$ \\
Lactose, \% & $4.61 \pm 0.04$ & $4.63 \pm 0.05$ & $4.64 \pm 0.05$ \\
Total solids, \% & $12.33 \pm 0.02$ & $12.42 \pm 0.03$ & $12.49 \pm 0.09$ \\
Solids nonfat(SNF),\% & $8.33 \pm 0.06$ & $8.39 \pm 0.08$ & $8.44 \pm 0.07$ \\
Ash, \% & $0.70 \pm 0.01$ & $0.73 \pm 0.02$ & $0.73 \pm 0.02$ \\
Fat yield, g/h/d & $492^{\mathrm{b}}$ & $529^{\mathrm{b}}$ & $548^{\mathrm{a}}$ \\
Protein yield, g/h/d & $371^{\mathrm{b}}$ & $398^{\mathrm{ab}}$ & $416^{\mathrm{a}}$ \\
\hline
\end{tabular}

a-b Means in the same row with different superscripts differ significantly at $\mathbf{P}<0.05$.

The superiority of productive performance for lactating goats with mixtures silages, especially G3, may be due to the positive associative effect between the two forages and the better condition of rumen fermentation as reported by Soliman et al (1997), Ahmed et al (2001 and 2013) and Ibrahim et al. (2012) Often the interaction between the components of the diet (mixture of silage in the present study) in both disestion and metabolism could be guarantee optimal rumen function and in turn significantly increasing the efficiency of milk production. El-Kholany (2004) found that milk yield was significantly-higher by lactating goats fed silage mixture (50\% maize- 50\% Sesbania) than those fed maize or Sesbania silage alone.

As regarded to milk composition, the data indicated that the differences among the experimental treatments on milk composition as fat, protein, total solids, SNF and Ash seemed to be unsignificant between them. The present results respecting milk composition are nearly similar with those obtained by Ahmed et al (2001) and Ibrahim et al (2008) on Zaraibi goats with little differences due to the individual differences among goats and feeding system.
Generally, yields of fat and protein were significantly higher with mixture silage-rations (G2 and G3) compared with those of berseem silage-ration (G1) as shown in Table (7). These results were related to the average milk yield as reported earlier study conductes by Ahmed et al (2001).

Daily feed intake, feed conversion and economic efficiency:-

Data of feed intake, feed conversion rate and economic efficiency of the dairy Zaraibi goats are summarized in Table (8). Results indicated that feed conversion calculated as DM and $\mathrm{CP} /$ milk yield was better for the two tested rations (G2 and G3) compared with those of control one (G1). Similar results were observed by El-Kholany (2004) and Ahmed et al(2013) using mixture of silage for dairy Zaraibi goats. Data in Table (8) indicated that the highest total feed cost(L.E $/ \mathrm{h} / \mathrm{d}$ ) was recorded for G1 (2.09) compared with other groups (1.97 and 1.77 for G2 and G3, respectively). The corresponding values of price of milk yield were $(4.305,4.603$ and $4.743 \mathrm{~L} . \mathrm{E} / \mathrm{h}$ for $\mathrm{G} 1, \mathrm{G} 2$ and G3, respectively). Therefore, the highest total feed cost/ $\mathrm{kg}$ milk (L.E) was observed for G1(1.70) and the lowest values were for G2 and G3 (2.5 and 1.31, respectively), due to the highest daily milk yield as well as the lowest price of feed consumption in the tested groups (silage mixture).

Accordingly, the economic efficiency was improved for the two tested rations $\mathrm{G} 2$ and $\mathrm{G} 3$ by $13.5 \%$ and $30 \%$, respectively compared with G1. This positive effect of Sesbania or beet-fodder on economic efficiency was observed also by Ahmed et al. (2001 and 2009) and Ibrahim et al. (2008) with lactating Zaraibi goats.

Table 8. Feed and economic efficiency for lactating Zaraibi goats fed different experimental rations.

\begin{tabular}{lccc}
\hline \multirow{2}{*}{ Items } & \multicolumn{3}{c}{ Groups } \\
\cline { 2 - 3 } & $\mathbf{G}_{\mathbf{1}}$ & $\mathbf{G}_{\mathbf{2}}$ & $\mathbf{G}_{\mathbf{3}}$ \\
\hline BW, kg & 39.8 & 40.2 & 40.0 \\
Metabolic body size, w ${ }^{0.75}$ & 15.84 & 15.96 & 15.91 \\
\hline Daily DM intake (g/h) & & & \\
CFM & 532 & 530 & 527 \\
Silage & 615 & 605 & 585 \\
Total DM intake & 1147 & 1135 & 1112 \\
DM intake, \% of BW & 2.88 & 2.82 & 2.78 \\
DM intake, g/kg w 0.75 & 72.41 & 71.1 & 69.89 \\
Roughage : concentrate, (R/C) ratio & $54: 46$ & $53: 47$ & $53: 47$ \\
CP intake g/h/d & 165 & 155 & 168 \\
Milk yield, g/h/d & 1230 & 1315 & 1355 \\
\hline Feed conversion & & & \\
Kg DM/ kg milk & 0.93 & 0.86 & 0.82 \\
Kg cp / kg milk & 0.134 & 0.118 & 0.123 \\
\hline Economic efficiency & \multicolumn{3}{|}{} \\
Cost of feed consumed, L.E/h/d & 2.09 & 1.97 & 1.77 \\
Price of milk, L.E & 4.305 & 4.603 & 4.743 \\
Feed cost / kg milk, L.E & 1.70 & 1.50 & 1.31 \\
Economic efficiency, \% & 2.06 & 2.34 & 2.68 \\
\hline
\end{tabular}

The prevailing prices, per ton, at time of the study are, CFM 2500 L.E, BS cost 300 L.E., BS/FB cost 235 L.E and 1 ton Sesbania sesban / fodder beet silage cost175 L.E while, 1 kg milk 3.5 L.E.

\section{CONCLUSION}

Based on the results of this study, it could be concluded that Sesbania-fodder beet silage can be successfully fed at ad lib. Level to with certain level of concentrate lactating goats without any adverse effect on milk production, ruminal functun, blood 
constituents, feed utilization efficiency and feeding values of the rations .

Further studies are needed to evaluate the Sesbania-fodder in different forms (hay- fresh- silage) at different levels as well as with other sources of energy and feed additive with different farm animals

\section{REFERANCES}

A.O. A. C. (1995). Official Methods of Analysis. (16th) Edt. Association Analytical Chemists, Washington, D.C., USA

Ahmed M.E., E.I. Shehata, M. E. El-Kholany, G.I. ElEmam, E.I. Khalifa and H. Bahery (2013).Productive performance of Zaraibi goats fed berseem and/or triticale silage. The 4thScientific Conference of Animal Production Research Institute, 184:192.

Ahmed, M. E. and M.E. El-Kholany (2012). Productive performance, some rumen parameters and blood profile of Zaraibi goats fed rations supplemented with chufa tubers during late pregnancy and suckling periods. J. Animal and Poultry Prod., Mansoura Univ., 3 (12): 537 - 555.

Ahmed, M. E., E.I. Shehata, F.F. Abou Ammou, Khalifa, E. I. and O.A. EL- Zolaky (2009). Productive and reproductive performance of Rahmani sheep fed rations containing reed forage (Arundodomax, L.) either fresh, hay or silage. Egyptian J. Sheep and Goat Sci., 4(1) 45.

Ahmed, M. E.; A.M. Abdelhamid, F.F. AbouAmou, E.S. Soliman, N.M. El-Kholy and E.I. Shehata (2001).Response of milk production of Zaraibi goats to feeding silage containing different levels of teosinte and kochia.Egyptian J. Nutrition and Feeds, 4 (Special Issue):141.

Conway, E.F.(1957). Micro diffusion Analysis and Volumetric Error. Rev. Ed. Lock Wood, London.

Duncan, D. (1955). Multiple ranges and multiple F-test. Biometrics, 11: 1.

El-Emam G. I., Y.H. Hafez, H. Bahery, E.I. Khalifa, E. I. Shehata and M. E. Ahmed (2014). Growth performance and some rumen and blood parameters of growing Rahmani lambs fed diets containing Triticale and berseem silages and their mixture. Egyptian J. Sheep and Goat Sci., 9(1) :67-76.

Elitok, B. (2012). Refernce values for hematological and biochemical parameters in Saanen goats breeding in Afyonkara hisar province. Kpcatepe Vet. J. $5: 7-11$.

El-kholany, M. E. ; G. A . Maged ; M. E. Ahmed ; A. M. Abdel-Gawad; M. A. Aboul - Omran and A. A. AlMowafy.(2016). Response of lactating zaraibi goats to diets containing sesbania sesban seeds as a new and high source of protein. J. Animal and Poultry Prod.., Mansoura Univ. Vol. (12) : 507- 513.

El-Kholany, M. E., E. S. Soliman, F. A. El-Sayed, and M. E. Ahmed (2013) Growth performance, some rumen parameters and blood profile of male Zaraibi goats fed diets containing Sesbania sesban seeds as a new source of protein. . Animal and Poultry Prod., Mansoura Univ., 4 (12):747759
El-Kholany, M. M (2004).Evaluation of some new green fodder for Farm animals .Ph.D. Thesis Fac. of Agric, Mansoura Univ.

El-Sayed, F. A. and W.M.A. Sadek (2015). Effect of feeding different types of silage (berseem or kochia and their mixture with fodder beet) on growth performance of growing male goats. J. Animal and Poultry Prod., Mansoura Univ., Vol. 6: (8): 567.

Figueiras, J.F., E. Detmann, M. O. Franco, E.D. Batista, W. L. S. Reis, M. F. Paulino and S.C. Valadares Filho (2016). Effect of supplements with different protein contents on nutritional performance of grazing cattle during the rainy season. Asian Australas J. Anim. Sci. vol. 29 (12) : 1710-1718.

Gabr A.A., A.Z. Mehrez, E.S.M. Soliman and M.ElKholany (1999). Response of lactating goats to diets containing reed grass ( Aroundo domax L.) versus sorghum plants, Egyptian J. Nutrition and feeds, 2 ( special Issue), 297.

Gabra, M. A., M. R. M. Moustfa, A. A. absel-Khabir and K. E. I. Etman (1992). Partial replacement of concentrate by fodder beet silage in metabolism trials with sheep and feeding trials with cows. J. Agric. Sci. Mansoura Univ. 17 (10) : 3140-3148.

Haggag M.El-H., E. S. Soliman and M.E. Ahmed (2002) Triticale forage as a feed for sheep. Proc., 1st Ann. Sc. Conf. Anim. And fish prod, Mansoura, Sep., P: 77.

Ibrahim, F.A., Soliman, E.S, A. A. Abd El-Hamid and M. E. Ahmed (2012). Growth performance and feed utilization efficiency of Rahmani lambs fed some legume and /or grass silages. Egyptian J. of Sheep and Goats Sciences, 7 (2): 1.

Ibrahim, F.A.M, M. E. Ahmed and Soliman, E.S (2008). Cultivation and evaluation of some green forage mixture and its utilization in feeding of lactating Zaraibi goats. Egyptian J. Nutrition and feeds, 11 (2) : 329 .

Jain, N. C.(1986). Veterinary Hematology 4 th Ed., Lea. and Febiger. Philadelphia.

Kaneko, J. J. (1989). Clinical Biochemistry of Animals.4thEd., Academic Press, Inc. USA

Ling, E.R. (1963). A Text Book of Dairy Chemistry.3rd Ed. Chapman and Hall Ltd., London.

Maged, G. A ; W.M .A . Sadik; G.I. El-Emam; M.E. ElKholany and T.H. El-Sawah. (2014). Milk production and feed utilization of zaraibi goats fed some forage protein sources such as berseem or kochia silage and their mixture with fodder beet. J. Animal and Poultry Prod.., Mansoura Univ. vol.5 (12) : 815-826.

Nguyen, T. T. G. , M. Wanapat, K. Phesatche and S. Kang (2017). Effect of inclusion of different levels of Leucana silage on rumen microbial population and microbial protein synsis in dairy steers fed on rice strow. Asian-Australes J. Anim. Sci. Vol. 30 (2) : 181-186. 
NRC (1981).Nutrient Requirements of Domestic Animals. Nutrient Requirements of Goats.National Research Council, Washington, D.C. USA, of Official Analytical Chemists, Washington, D.C., USA.

Oni,A.O., C. F. I. Onwuka, O.O. Oduguwa, O.S. Onifade, O.M. Arigbede and E. N. Olatunji (2006). Utilization of certain pulp based diets and Entera Lobium Cyclo carpum foliage (Jacq. Griseb) by African Dwarf goats. J. Anim. Vet. Adv. 5 : 814-818.

Rammah, A. M. , Ali, F.M. and Hassan, M. T. (1984) Evaluation of fodder beet cultuvars for different locations and years. EMCIP publications, $1: 215$.

SAS (2003).SAS. ISTATR User Guid: Statistics. Ver. 9.1; Fourt "Edition SAS Institute Inc; Cary; Nc.

Shehata E.I, M.E. Ahmed, A.M. Abdelhamid, Faten F. Abou Ammou and M. El-H. Haggag (2001) Comparative nutritive values of silage ration containing different level of teosinte and Kochia . Egyptian J. Nutrition and feeds, (4): 129.

Shultz, T.A. and E. Shultz (1970). Estimation of rumen microbial nitrogen by three analytical methods. J. Dairy Sci , pp: 53.
Soliman, E.S, A.E.M. Kinizy, Bahira K. Mohamed and M. El-H. Haggag (1997). Studies on using sesbania and Teosinte forage in feeding of growing Zaraibi goats Egypt. J. Appl. Sci.,12 (5) $: 36$.

Tag El-Din A. E., A. A. Nour, M. A. Ahmed and S. M. Zahran (1991). Utilization of Kochia indica in complete diets for ruminants. Alex. J. Agric. Res., P: 36.

Warner, A.C.I. (1964). Production of volatile fatty acids in the rumen, methods of measurements. Nutr. Abst. \& Rev., (34): 339.

Zaid A. M. , E. I. Shehata, M. E. Ahmed and A. M. Abd el-Gawad (2009). Growth performance of male Zaraibi goats fed teosinte forage in rations differing in roughage : concentrate ratio. Agric. Sci. Mansoura Univ., 34 (11) : 10441.

\section{تأثير استخدام أنواع مختلفة من مخاليط السيلاج في علائق الماعز الزرايبي الحلاب علي كل من إنتاج اللبن، كفاءة

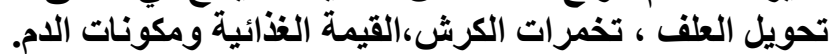

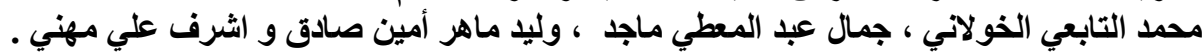

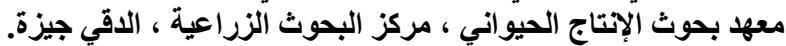

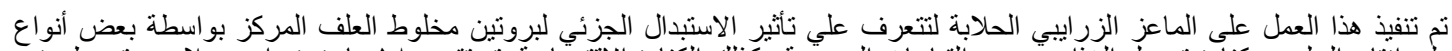

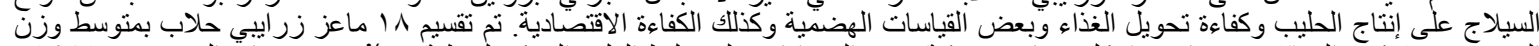

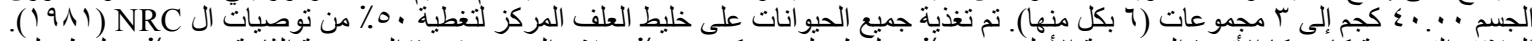

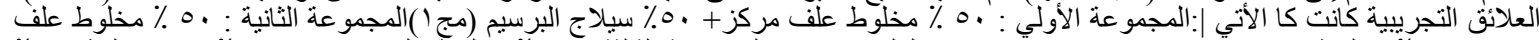

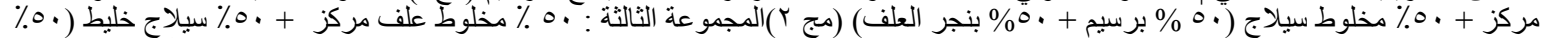

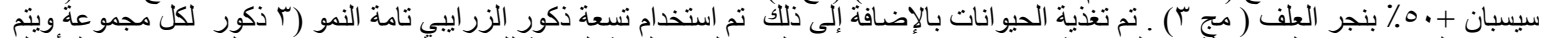

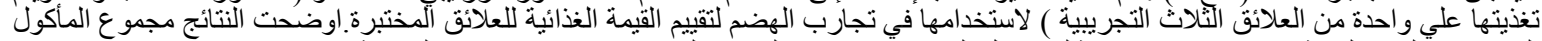

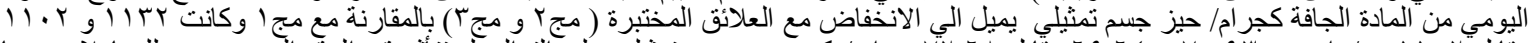

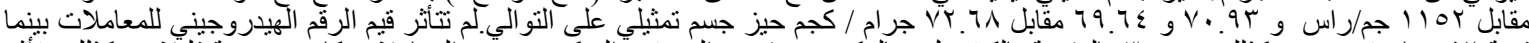

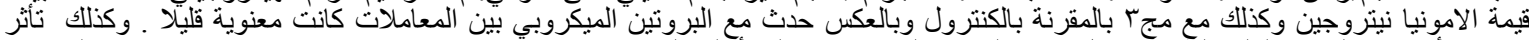

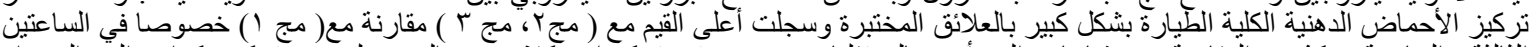

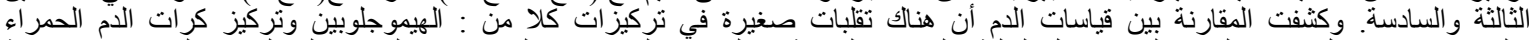

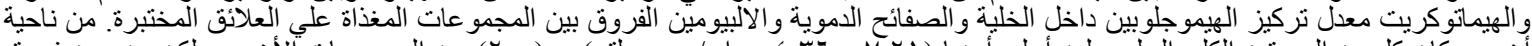

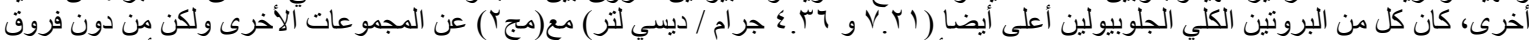

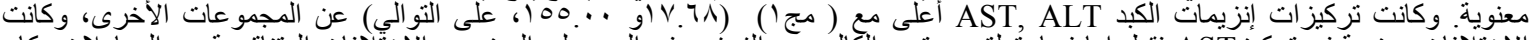

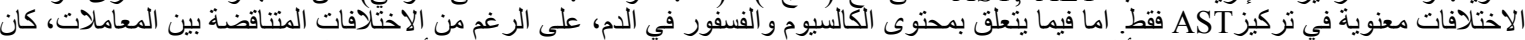

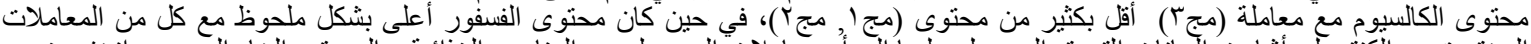

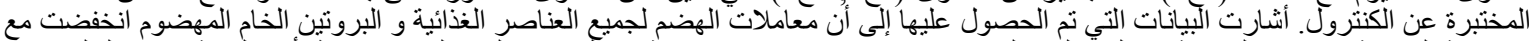

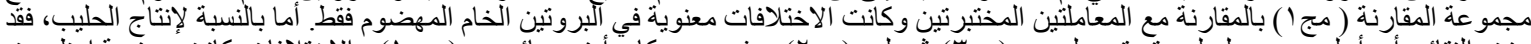

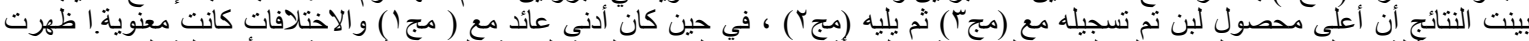

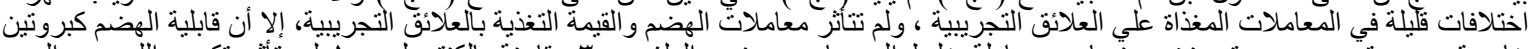

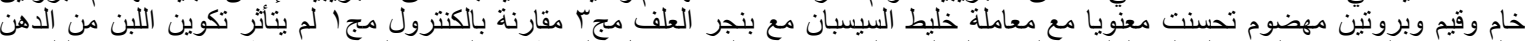

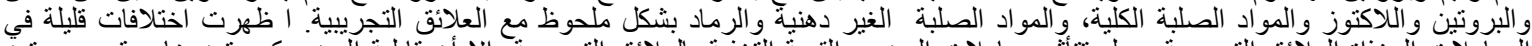

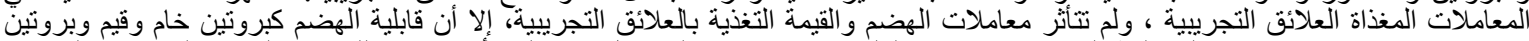

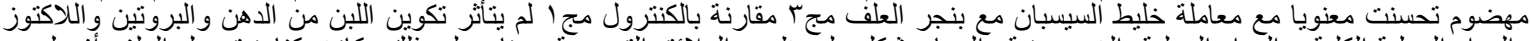

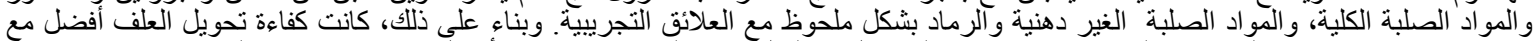

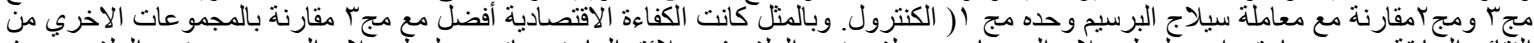

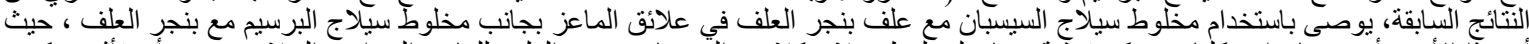

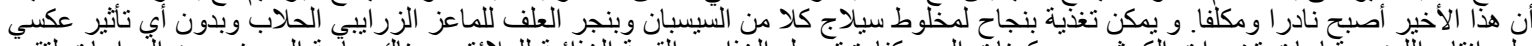

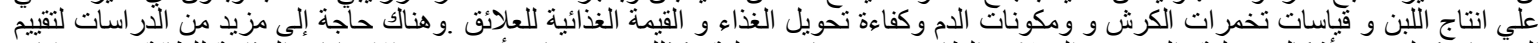

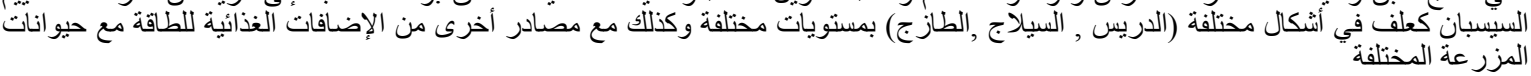

